\title{
Econometric Analysis of Residential Sector Gas Demand Elasticities in Gas Exporting Countries
}

\author{
Eshagh Mansourkiaee ${ }^{1} \&$ Hussein Moghaddam ${ }^{2}$ \\ ${ }^{1}$ Researcher (GECF Ex-Energy Econometrician), NIOC, Tehran, Iran \\ ${ }^{2}$ Senior Energy Analyst, GECF, Doha, Qatar \\ Correspondence: Hussein Moghaddam, GECF, Doha, Qatar.
}

Received: June 17, 2021

Accepted: July 11, 2021

Online Published: July 15, 2021

doi:10.5539/eer.v11n2p1

URL: https://doi.org/10.5539/eer.v11n2p1

\begin{abstract}
This paper examines how residential sector gas demand in gas exporting countries response to changes by taking into consideration the economic variables. For this purpose, the short and long-run price and income elasticities of residential sector gas demand in the GECF countries for 2000 and 2019 are measured. Using Cobb-Douglas functional form, this paper applies the bounds testing approach to co-integrate within the framework of ARDL (Autoregressive Distributed Lag). Findings of this research show that there is a significant long-run relationship in nine GECF countries, including Algeria, Egypt, Iran, Malaysia, Norway, Peru, Russia, Trinidad and Tobago and Venezuela, that use gas as a source of energy in their residential sector. On average, long-rung income elasticity for underlying countries is 2.65 , while long-run price elasticity is negative and calculated at 0.79 . This shows that in considered gas exporting countries, residential sector gas demand is very sensitive to income policies, while the price policies impact on demand is more limited. Furthermore, short-run income and price elasticities are estimated at 6.99 and -0.02 (near zero) respectively, which implies that natural gas is very inelastic to price, as a result, price policies are unable to make significant changes in demand over the short-term. Meanwhile, as expected short-run price elasticity is lower than long-run elasticities, indicating that gas exporting countries are more responsive to price in the long-term than in the short-term. Finally, it was found that most of the preferred models have empirical constancy over the sample period.
\end{abstract}

Keywords: GECF, gas exporting countries, ARDL model, Bound F-test cointegration, residential gas demand, elasticity

\section{Introduction}

This paper aims to investigate how residential sector gas demand responses to changes in gas price and economic activity. Therefore, obtained results help to understand gas demand responsiveness in several GECF countries. Furthermore, results can be used for benchmarking, as well as an input into Energy Models across the world. The result is also helpful for policymakers who are interested to know how different prices and income policies, such as energy taxation or carbon price may impact residential sector gas demand in their respective countries. Behavioural responses to price-based incentives have important implications for strategies to improve energy efficiency and reduce negative energy-related externalities (Gao et al., 2020). Given that climate mitigation strategies are often based on lowering the carbon intensity of GDP, it is equally important to know whether the income elasticity is less than the unity, which implies that energy intensity will fall in a business-as-usual economic growth scenario (Liddle et al., 2020). Consequently, both price and income elasticities are significant for the design of energy and climate policy.

The Gas Exporting Countries Forum (GECF) is a gathering of the world's leading gas producers and was set up as an international governmental organization in 2009. As of May 2021, the Member Countries of the Forum are Algeria, Bolivia, Egypt, Equatorial Guinea, Iran, Libya, Nigeria, Qatar, Russia, Trinidad and Tobago, and Venezuela. However, Angola, Azerbaijan, Iraq, Kazakhstan, Malaysia, Norway, Peru, and the United Arab Emirates have the status of Observer Members. This paper therefore analyse the gas demand elasticities in the residential sector of the GECF members and observers countries.

This paper is organized as follows. The next section presents the literature review. Section 3 illustrates the theoretical framework and econometric methodology, which is based on the ARDL bound test cointegration 
approach. The description of data and required standard tests to validate the underlying approach, the result of the analysis and the estimated elasticity coefficients are shown in section 4, together with thediagnostics and stability test. Finally, the conclusion will be discussed in section 5 .

\section{Literature}

There are numerous studies that tried to estimate the price and income elasticities of natural gas demand in different countries over different periods. Considering that these studies have employed different econometric approaches, conflicting and diverse results are not surprising. Many of these studies, however, use time-series data to estimate price and income elasticities (Dong et al., 2019). For example, Payne et al. (2011) use the autoregressive distributed lag (ARDL) approach and time-series data for 1970 through 2007 to investigate the price elasticity of natural gas demand for the state of Illinois in the United States of America (USA). Using the ARDL method and time-series data for the period of 1992-2012, Zhang et al. (2018) estimate the price and income elasticities of natural gas demand in China. To a lesser extent, certain studies use cross-sectional data. For instance, Alberiniet al. (2011) study the price elasticity of residential demand for natural gas in the USA, employing nationwide household-level data. Sun and Ouyang (2016) estimate the price and expenditure elasticities of residential natural gas demand in China's residential sector. In another study, Burke and Yang (2016) estimate price and income elasticities of natural gas demand using cross-sectional data by covering 44 countries. The third group of studies are those that use panel data to estimate the price and income elasticities of natural gas demand, such as Ascheet al. (2008) for 12 European countries, Andersen et al. (2011) for 13 Organization for Economic Cooperation and Development (OECD) countries, Bilgili (2014) for 8 OECD countries, Dilaveret al. (2014) for European countries and Dong et al. (2019) for 30 China's provinces.

The literature review shows that price and income elasticities have been extensively studied in OECD countries,although, there are relatively few estimates of such elasticities for non-OECD countries (Liddle et al.,2020). Despite its importance for policy purposes (including climate policy and the energy transition), the literature on the price elasticity of natural gas demand in the residential sector is very limited (Alberiniet al., 2020). Auffhammer and Rubin (2018) identify a total of nine studies mainly from the US, the UK and Germany. Moreover, recent studies that focus onthe econometric analysis of residential sector natural gas demand are rare, whilethe old ones usually suffer from the problems related to non-stationarity in the data, as a consequence, the possibility of 'spurious' regressions (Bernstein and Madlener, 2011). Table 1 provides an overview of studies in which the price and income elasticities of demand in the household sector have been examined. As table 1 indicates, most of these studies are related to the US, UK and few other developed countries. For example, Ascheet al. (2008) analyze residential natural gas demand in $12 \mathrm{EU}$ member countries, using panel data for the period between 1978 and 2002. The study estimates an income elasticity of 3.32 in the long run and 0.81 in the short run. The long-run price elasticity is estimated at -0.10 , while the short run is -0.03 . Using fixed effects to estimate residential natural gas demand elasticities in the Netherlands, Berkhoutet al. (2004) estimate the long-run income and price elasticities of -0.27 (a counterintuitive value) and -0.19 (not significant), respectively. Joutzet al. (2008) estimate elasticities for the US using household panel data. They estimatea price elasticity of 0.18 for the long run and -0.09 for the short run. Applying an error-components and seemingly unrelated regression (SUR) approach on US household data for1960 to 1983, Lin et al. (1987) estimate 0.57 elasticities for the income in the long run, and 0.11 in the short run, respectively. Their estimates for price elasticities are -1.22 for the long run and-0.15 for the short run. Using time-series data from 1980 to 2008, and the autoregressive distributed lag (ARDL) bounds testing procedure, Bernstein and Madlener (2011) analyzed residential natural gas demand elasticities in twelve OECD countries. Their estimation of long-run price and income elasticities were -0.51 and 0.94 , respectively. They estimate the short-run price elasticity of -0.24 and the short-run income elasticity, which was 0.45 , both almost half of that for long-run counterparts.

Except for the US and Australia, the two top gas producers, which are not included in the list of GECF countries, few studies have been conducted to assess price and income elasticities of natural gas demand in the residential sector of gas exporting countries as GECF. According to table 1, only one study byMarkos and Chahir (2021) thatexamines household sector gas demand elasticities in Egypt, is a member of GECF. The study estimates elasticities using residential natural gas demand data for 1983-2015. Their results show that in the long run, the price elasticity of the household sector is -1.29 , reflecting an elastic demand. However, the short-run price elasticity is insignificant, as well as the short-run income elasticity.

Afimia (2019) conducted a study on estimating natural gas demand elasticities in Nigeria, another GECF member country, using the ARDL bounds test approach, however with aggregate natural gas demand time-series data (not residential sector) spanning 1981-2008. The study revealed that the short-run price elasticity of demand is -0.15 , which is statistically significant. The long-run estimate of price elasticity of natural gas demand is also 
-0.089 , which is also statistically significant. However, both short and long run estimations of income elasticities showed to be insignificant.

As such, the main contribution of this study is to provide price and income elasticity of natural gas demand for GECF gas exporting countries to fill the gap in the literature. The results of this study can be important for gas players around the world, as gas demand behaviour in the main gas producing countries gathered in GECF can have a profound impact on gas consumer countries by disrupting sustainable gas supply.

Table 1. An Overview of residential natural gas demand studies on price and income elasticities

\begin{tabular}{|c|c|c|c|c|}
\hline \multirow[t]{2}{*}{ Author(s) } & \multirow[t]{2}{*}{ Study coverage } & \multirow[t]{2}{*}{ Data \& period } & \multicolumn{2}{|c|}{ Elasticity estimate } \\
\hline & & & Price & Income \\
\hline $\begin{array}{l}\text { Houthakker and Taylor } \\
\text { (1970) }\end{array}$ & US & Time series & -0.15 & - \\
\hline Tinicetal.(1973) & Alberta, Canada & Cross-section data, 1973 & -2.13 to -0.47 & 0.02 \\
\hline \multirow[t]{2}{*}{ Lin et al. (1987) } & \multirow[t]{2}{*}{ US } & Panel annual data, & L: -1.22 & L: 0.57 \\
\hline & & $1960-1983$ & S: -0.15 & S: 0.11 \\
\hline Herbert and Kreil (1989) & US & Monthly time series & -0.36 & _- \\
\hline Maddalaet al. (1997) & US & panel & -0.09 to -0.18 & _- \\
\hline $\begin{array}{l}\text { Metcalf and Hassett } \\
\text { (1999) }\end{array}$ & US & $\begin{array}{l}\text { Residential Energy Consumption Survey } \\
\text { (RECS) Household panel, } 1987\end{array}$ & -0.08 to -0.71 & - \\
\hline Garcia-Cerrutti (2000) & Calif. County & $\begin{array}{l}\text { Residential Energy Consumption Survey } \\
\text { (RECS) Panel }\end{array}$ & -0.11 & - \\
\hline Berkhoutet al. (2004) & Netherlands & Panel annual data, 1992-1999 & L: -0.19 & $\mathrm{~L}:-0.27$ \\
\hline Rehdanz (2007) & Germany & Household panel & -0.44 to -0.63 & - \\
\hline Ascheet al. & $12 \mathrm{EU}$ & Panel annual data, & L: -0.10 & $\mathrm{~L}: 3.32$ \\
\hline (2008) & countries & 1978-2002 & S: -0.03 & S: 0.81 \\
\hline Joutzet al. (2008) & US & Panel monthly data, 1980-unclear & $\begin{array}{l}\text { L: }-0.18 \\
\text { S: }-0.09\end{array}$ & - \\
\hline $\begin{array}{l}\text { Meier and Rehdanz } \\
\text { (2010) }\end{array}$ & UK & Household panel & -0.34 to -0.56 & - \\
\hline $\begin{array}{l}\text { Davis and } \\
\text { Muehlegger(2010) }\end{array}$ & US & Panel & -0.278 & - \\
\hline Alberiniet al. (2011) & US & $\begin{array}{l}\text { mixed panel/multi-year cross-sections, } \\
\text { 1999-2007 }\end{array}$ & -0.57 to -0.69 & - \\
\hline \multirow{2}{*}{$\begin{array}{l}\text { Bernstein and Madlener } \\
\text { (2011) }\end{array}$} & \multirow{2}{*}{$\begin{array}{l}12 \text { OECD } \\
\text { Countries }\end{array}$} & \multirow[t]{2}{*}{ Time series, 1980-2008 } & L: -0.51 & L: 0.94 \\
\hline & & & S: -0.24 & $\mathrm{~S}: 0.45$ \\
\hline $\begin{array}{l}\text { Hausman and Kellogg } \\
\text { (2015) }\end{array}$ & US & Panel & -0.11 & - \\
\hline Sun and Ouyang (2016) & China & Household data, 2013 & 0.78 & 0.80 \\
\hline \multirow[t]{2}{*}{ Afimia (2019) } & \multirow[t]{2}{*}{ Nigeria } & \multirow[t]{2}{*}{ Time series, 1984-2016** } & L: -0.089 & L: $0.043^{*}$ \\
\hline & & & S: -0.15 & S: $0.13^{*}$ \\
\hline Alberiniet al. (2020) & Ukraine & $\begin{array}{l}\text { Household panel monthly data, Jan. 2013- } \\
\text { Apr. } 2017\end{array}$ & S: -0.16 & - \\
\hline \multirow{2}{*}{$\begin{array}{l}\text { Markos and } \\
\text { Chahir(2021) }\end{array}$} & \multirow[t]{2}{*}{ Egypt } & \multirow[t]{2}{*}{ Time series, $1983-2015$} & L: -1.29 & $\mathrm{~L}:-3.77$ \\
\hline & & & S: $-0.01^{*}$ & S: $0.22 *$ \\
\hline
\end{tabular}

Source: Authors, Bernstein and Madlener (2011), Auffhammer and Rubin (2018), Note: * denote insignificant statistic, ** Data include Nigeria aggregate natural gas demand 


\section{Method}

\subsection{Theoretical Model}

This paper conducts demand analysis for one energy carrier (gas) for one specific sector (residential). Therefore, it uses data at the lowest level of aggregation possible. This approach allows reducing the disadvantages that may raises from a heterogeneity of the consumer characteristics (difference in consumer behaviour and technology) associated with aggregated data. As highlighted by Pesaranet al. (1998, p.46), it is essential for an econometric model to use data "as homogenous a grouping of consumers as feasibleit is".

To analyze the long run gas demand relationship for the residential sector, it was assumed that gas demand is the function of the following components:

$$
G_{t}=f\left(Y_{t}, P_{t}, X_{t}\right)
$$

Equation (1) contains $G_{t}$, which is residential gas consumption per capita, $Y_{t}$ as real income per capita, $P_{t}$ as the real gas price for residential use and $X_{t}$, which is defined as other exogenous variables that may play an important role in driving natural gas demand in the residential sector. Meanwhile, a dummy variable can be taken into account accordingly. To estimate equation (1), the following constant elasticity functional form was used:

$$
G_{t}=\alpha_{0} \exp \left(\alpha_{1} t\right) Y_{t}^{\alpha_{2}} P_{t}^{\alpha_{3}} X_{t}^{\alpha_{4}}
$$

Where $\alpha_{2}, \alpha_{3}$ and $\alpha_{4}$ are constant elasticity coefficients of demand with respect to income, price and $X_{t}$ while $X_{t}$ represents other exogenous variables. $X_{t}$ is initially defined as combined cooling and heating degree days as other studies suggest. Then trend and structural break are included, where it is appropriate. However, if these variables are not significant, we omit them to gain degrees of freedom.According to Olsen (1988), to capture the evolution of energy use over time, a dynamic framework is needed. One of the early methods widely employed to capture the dynamics interaction is the Auto Regressive Distributed Lag Model (ARDL). In its basic form, an ARDL regression model is given by:

$$
Y_{t}=\beta_{0}+\beta_{1} Y_{t-1}+\cdots+\beta_{k} Y_{t-k}+\alpha_{0} X_{t}+\alpha_{1} X_{t-1}+\alpha_{2} X_{t-2}+\cdots+\alpha_{j} X_{t-j}+\varepsilon_{t}
$$

Where $\varepsilon_{t}$ is a white noise error term. The model is called "autoregressive", as the dependent variable $Y_{t}$ is correlated with $\operatorname{lag}(\mathrm{s})$ of itself.It also has a "distributed lag" component, as independent variables $X_{t}$ influence the dependent variable with a time lag. Given the presence of lagged values of the dependent variable as regressors, OLS estimation of an ARDL model will yield biased coefficient estimates. If the error term, $\varepsilon_{t}$, is autocorrelated, the OLS will also be an inconsistent estimator, and in this case, Instrumental Variables estimation was generally used to estimate these kinds of models. The sign of the constant elasticity coefficient of income is expected to be positive, while the price is assumed to be negative.To extract econometric specification of the long-run residential natural gas demand function, we recall equation (2) and bytaking natural logarithms of that we have:

$$
g_{t}=\alpha_{0}+\alpha_{1} t+\alpha_{2} y_{t}+\alpha_{3} p_{t}+\alpha_{4} w_{t}+\varepsilon_{t}
$$

Where $g_{t}=\ln \left(G_{t}\right) ; y_{t}=\ln \left(Y_{t}\right) ; p_{t}=\ln \left(P_{t}\right)$ and $w_{t}=\ln \left(X_{t}\right)$. The coefficients of $\alpha$ measure long-run multipliers and $\varepsilon_{t}$ is a white noise error term.

According to Gujarati (2009), regression of time series can give spurious results and one way to guard against is to ensure that time series are cointegrated. For this purpose, in this paper, the bounds testing cointegration approach is used, which has been developed by Pesaran and Shin (1999) and Pesaranet al. (2001). Although, ARDL modelling has been used for decades, it has been recently attracted considerable attention for testing the presence of a long-run relationship between economic timeseries. The ARDL bound test for cointegration is the "new approach to the problem of testing the existence of a level relationship between a dependent variable and a set of regressors when it is not known with certainty whether the underlying regressors are trend or first-difference stationary. The proposed tests are based on standard F- and t-statistics used to test the significance of the lagged levels of the variables in a univariate equilibrium correction mechanism" (Pesaranet al., 2001).

An ARDL Bound testing cointegration has several advantages over conventional cointegration testing. Firstly, the methodology can be applied with a mixture of $\mathrm{I}(0)$ and $\mathrm{I}(1)$ regressors. Secondly, it does not need information regarding the order of integration of the variables included in the analysis. Therefore, we do not need to conduct pretesting of unit root (stationary) of time series included in the model unlike the other conventional techniques, such as the Johansen approach. However, it still needs to make sure that none of the variables is $\mathrm{I}(2)$, as such data will invalidate the bound testing approach. Thirdly, this approach allows the long-run relationship to be estimated by OLS once the lag order of the model is identified. Finally, the test is 
rather more efficient in small or finite sample data sizes, as it is the case of this study.

Following Pesaranet al's (2001) bound testing approach, subsequent steps were used to find out whether our specified long-run relationship in equation (3) is cointegrated. The first step is to estimate an unrestricted error-correction model (ECM) using OLS as follows:

$$
\begin{aligned}
& \Delta g_{t}=c_{0}+\gamma t+\delta_{1} g_{t-1}+\delta_{2} y_{t-1}+\delta_{3} p_{t-1}+\delta_{4} w_{t-1}+\sum_{i=1}^{k} \rho_{1, i} \Delta g_{t-i}+\sum_{i=1}^{l} \rho_{2, i} \Delta y_{t-i}+ \\
& \sum_{i=1}^{m} \rho_{3, i} \Delta p_{t-i}+\sum_{i=1}^{n} \rho_{4, i} \Delta w_{t-i}+\epsilon_{t}
\end{aligned}
$$

Where the $\delta$ are the long-run coefficients, $c_{0}$ is a drift term, $\rho$ are the short-run multipliers and $\epsilon_{t}$ is a white noise error term, while current values of $\Delta y, \Delta p$ and $\Delta w$ are excluded from the model structure.

In the next step, the Wald or F-statistic in a generalized Dicky-Fuller type regression will be used to test the significance of lagged levels of the variables under consideration in a conditional unrestricted equilibrium correction model (ECM) (Pesaran et al., 2001). In other words, we test the null hypothesis of no exist of long-run relationship and all long-run coefficients in equation (5) are zero against this alternative hypothesis, that at least one long-run coefficient is non-zero.

Therefore, Wald test is conducted as the following:

$$
\begin{gathered}
H_{0}: \delta_{1}=\delta_{2}=\delta_{3}=\delta_{4}=0 ; \\
H_{1}: \delta_{1} \neq 0, \text { or } \delta_{2} \neq 0, \text { or } \delta_{3} \neq 0, \text { or } \delta_{4} \neq 0 .
\end{gathered}
$$

Critical values for F-statistics were obtained by Pesaranet al. (2001, p.300-4). For the different number of regressors and whether deterministic terms (intercept and trend) are included, two lower and upper bounds are supplied. The lower bound is based on the assumption that all the variables are $\mathrm{I}(0)$, while the upper bound assumes all the variables are I(1). Therefore, on one hand, if the computed F-statistic falls below the lower bound, the null hypothesis of no long-run relationship is not rejected. On the other hand, if the calculated F-statistics falls above the upper bound, the null hypothesis of no cointegration can be rejected, irrespective of whether the regressors are $\mathrm{I}(0)$ or $\mathrm{I}(1)$. However, if the F-statistic falls between the bounds, the result is inconclusive. It is important to mention that even though the F-statistic bounds test may reject the null hypothesis of no cointegration, there is still a risk of nonsensical or degenerate cointegration depending on data generating processes (DGPs) considered in the study of Pesaran, Shin, and Smith (2001). While, in the latter case (degenerate) estimated coefficients are still valid, in the former case (nonsensical), we are not allowed to proceed with estimating the speed of adjustment. To avoid this situation, however, T-bounds test critical values are provided to determine which alternatives emerge. Again, if the absolute value of the T-Bounds test is greater than the absolute value of either the I(0) or I(1) T-bounds, the null hypothesis should be rejected, and it is concluded that the cointegrating relationship is either of the usual kind or valid, but degenerate. Then, visualizing the fit between the dependent variable and the long-run equation can lead us to determine which alternative is valid.

Given that the existence of the long-run relationship is concluded by bound F-test, then the order of the ARDL model (optimal lag lengths) in equation (5) can be identified by using Akaike Information Criterion (AIC) and the Schwarz Bayesian Criterion (SBC). Meanwhile, a key assumption in the bound F-test procedure is that residuals of equation (5) are not serially correlated. Consequently, the Breusch-Godfrey Serial Correlation LM Test will be used to ensure that error terms are serially independent. We also make sure that the model is not suffering from the heteroskedasticity problem, as this will make the coefficients of estimation inefficient.

Once the cointegration is established, the conditional ARDL $(\mathrm{k}, 1, \mathrm{~m}, \mathrm{n})$ long term model for residential natural gas consumption can be estimated as:

$$
g_{t}=\beta_{0}+\beta_{1} t+\sum_{i=1}^{k} \beta_{2, i} g_{t-i}+\sum_{i=1}^{l} \beta_{3, i} y_{t-i}+\sum_{i=1}^{m} \beta_{4, i} p_{t-i}+\sum_{i=1}^{n} \beta_{5, i} w_{t-i}+z_{t}
$$

Where $z_{t}$ is an error term and $\mathrm{k}, \mathrm{l}, \mathrm{m}$ and $\mathrm{n}$ are the lag lengths of the respected variables.Accordingly, the long-run coefficients in Equation (4) can be extracted from estimated parameters in Equation (6) as follows:

$$
\begin{gathered}
\alpha_{0}=\frac{\beta_{0}}{\left(1-\sum_{i=1}^{k} \beta_{2, i}\right)}, \\
\alpha_{1}=\frac{\beta_{1}}{\left(1-\sum_{i=1}^{k} \beta_{2, i}\right)} \text { and } \\
\alpha_{s}=\frac{\sum_{i}^{r} \beta_{s}}{\left(1-\sum_{i=1}^{k} \beta_{2, i}\right)}
\end{gathered}
$$

With $s=3,4,5$ and $r=k, l, m, n . \alpha_{0}$ is constant and $\alpha_{1}$ is also represent a deterministic trend. The 
$\alpha_{s}$, however, are the long-run coefficients (here elasticities) for income, price and another exogenous variable initially weather control variable (combined heating and cooling degree days).

Finally, we obtain the short-run dynamic parameters by estimating an error correction model as follows:

$$
\begin{gathered}
\Delta g_{t}=\varphi_{0}+\varphi_{1} \Delta t+\sum_{i=1}^{k} \varphi_{2 . i} \Delta g_{t-i}+\sum_{i=1}^{l} \varphi_{3, i} \Delta y_{t-i}+\sum_{i=1}^{m} \varphi_{4, i} \Delta p_{t-i}+\sum_{i=1}^{n} \varphi_{5, i} \Delta w_{t-i} \\
+\varphi_{e c t} E C T_{t-1}+u_{t}
\end{gathered}
$$

Where $\mathrm{ECT}_{\mathrm{t}-1}$ is the OLS residual series resulted from the long-run cointegration relationship in equation (4). As a result, $\varphi$ 's are the dynamic short-run coefficients of the model's convergence to long-run equilibrium the year before, and $\varphi_{\text {ect }}$ is the speed of adjustment.

\section{Results}

\subsection{Data Description}

In this paper, the estimation of residential natural gas consumption for GECF countries is based on the annual time series data for the span of 2000 to 2019 and on a country-by-country basis. From equation (4), $G_{t}$ is defined as residential consumption of gas per capita measured as toe (Ton Oil Equivalent), $Y_{t}$ represent household net disposable income per capita measured as real million US\$ (the base year 2019), while $P_{t}$ is the value of residential sector gas price presented at real US\$ per toe (the base year 2019). Since data on household net disposable income is not directly available for GECF countries, real GDP has used as the best approximate for $Y_{t}$ each was more appropriate.

The data for residential natural gas consumption and gas prices are obtained from IEA after cross-check with data made available on the JODI Gas platform and adjusted if necessary. GDP and exchange rate data sourced from IMF and different national sources, while population data obtained from the UN population division.

We construct the real price of natural gas using natural gas prices on local currencies divided by US $\$$ exchange rate normalized to $2019=100$. We used initially weather control as a fixed explanatory variable, but we removed it later as this variable was not significant. Overall, we preferred to remove insignificant variables to gain more degrees of freedom. In case of Iran, we also added a dummy variable to capture the strong currency devaluation caused under the impulsion of sanction.

Figures 1 to 4 depict the time series of described variables. Visual inspection of the time series reveals the following trends:

i. There is a considerable pattern's disparity across different countries' residential sector gas consumption (Figure 1). While gas consumption in the residential sector of Norway, Peru and Bolivia surged over historical years with average annual growth of $25 \%, 24 \%$ and $21 \%$ respectively, Algeria and Egypt have also seen a strong growth of around 10\%. It grew slightly in Iran and Azerbaijan with around 5\% per annum. However, gas consumption in the residential sector of Russia and Kazakhstan has increased very slowly with less than $1 \%$ and for that of Trinidad and Tobago, Malaysia and Venezuela showed a downward trend with $2.8 \%, 6 \%$ and $8.7 \%$ respectively.

ii. Most countries reveal an overall downward trend in gas price (Figure 2), except Norway, Russia and Trinidad and Tobago. Norway has the most expensive gas price amongst the examined countries; it shows a price of $1060 \mathrm{USD} /$ toe by the year 2019, which is more than three times higher than the second-highest price, for instance, Malaysia with around $300 \mathrm{USD} /$ toe.The largest decline has posted by Venezuela with an almost $90 \%$ decline in gas price over the period, followed by Iran and Kazakhstan. In all series, the decreasing effect of local currency or depreciation of indigenous money against the US dollar can be observed.

iii. All countries show an overall upward trend in real GDP (Figure 3). The only exception is Venezuela, that has experienced a large decrease of $225 \%$ in its real GDP over the last 5 years. In Venezuela, real GDP starts to decline from 2014. Other countries, however, have seen an increase in their GDP that varies from a minimum of $12 \%$ in Trinidad to the maximum of $42 \%$ in case of Russia. Looking at the population data (Figure 4), it shows that all countries except Russia have seen an increase in their population. However, the population has increased moderately in most countries. All other countries show an increase of less than $2 \%$ on an annual average, except Egypt. The population starts to decline 
in Russia from 2000, but then the trend bottom-up around the year 2008, and only at that point, the rising trend can be identified. Nevertheless, the Russian population in 2019 is still lower than in 2000.

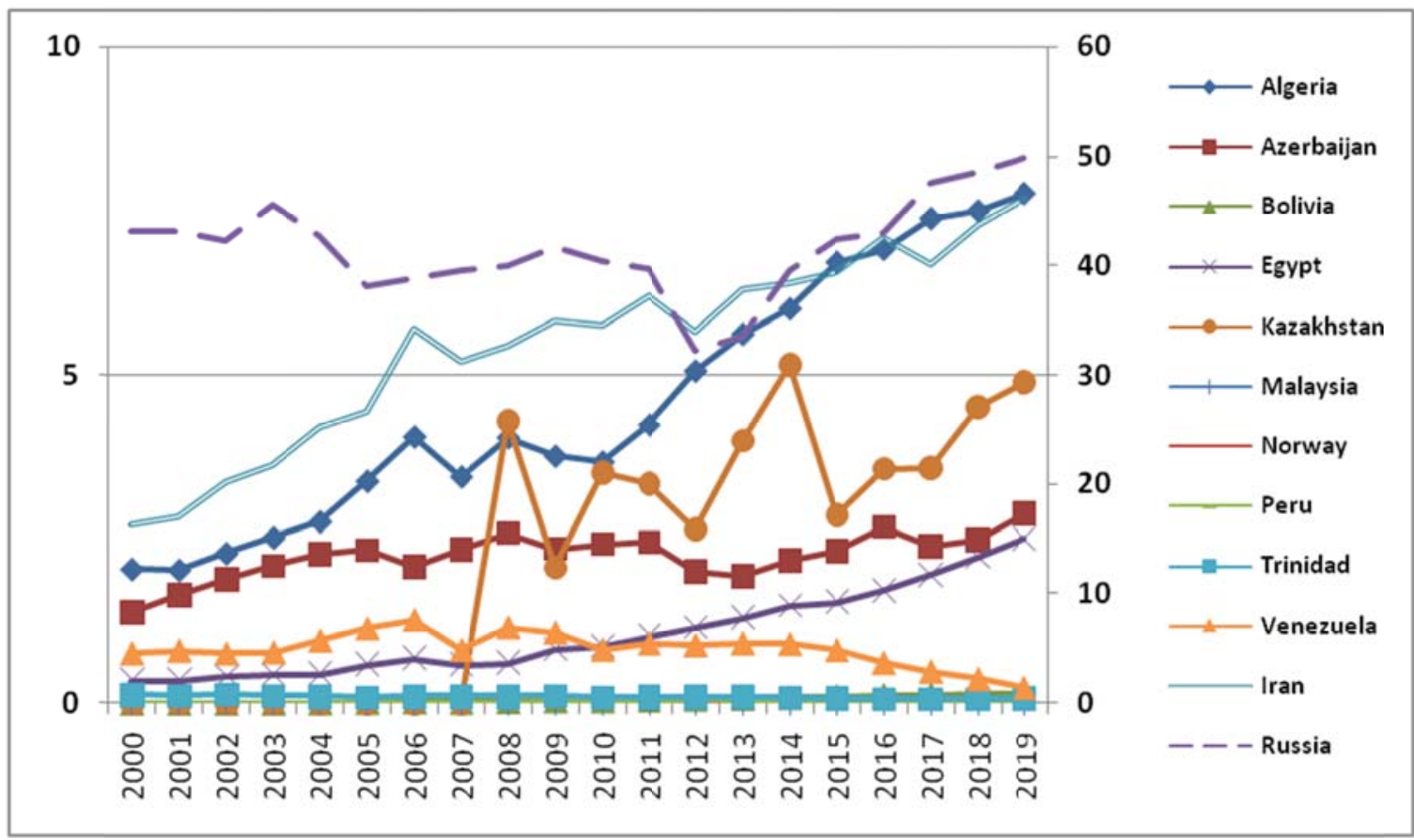

Figure 1. Residential natural gas consumption (in mtoe). Right Axis: Iran and Russia Source: Authors

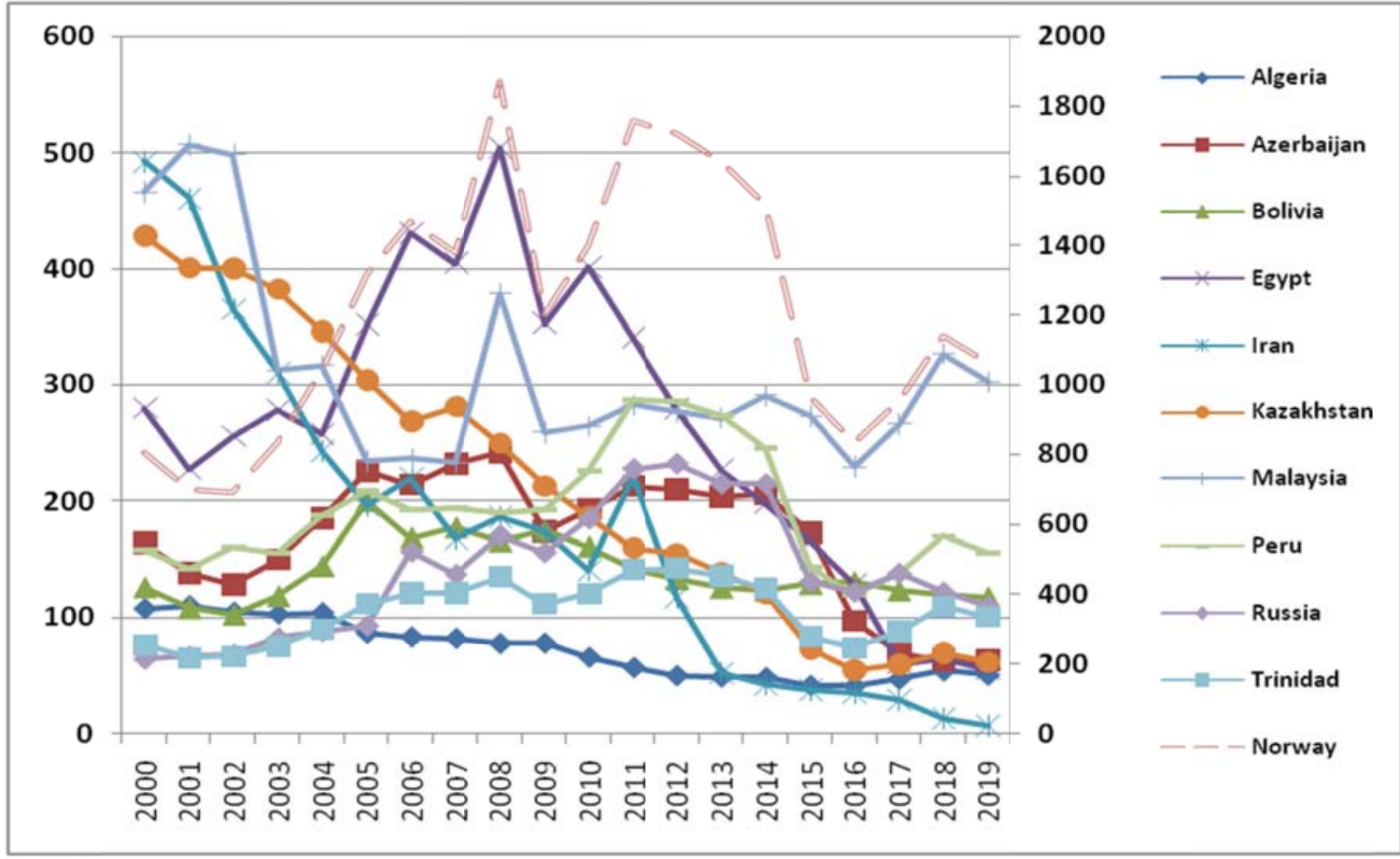

Figure 2. Residential natural gas price (in real USD/toe), excluding Venezuela. Right Axis: Norway.

Source: Authors 


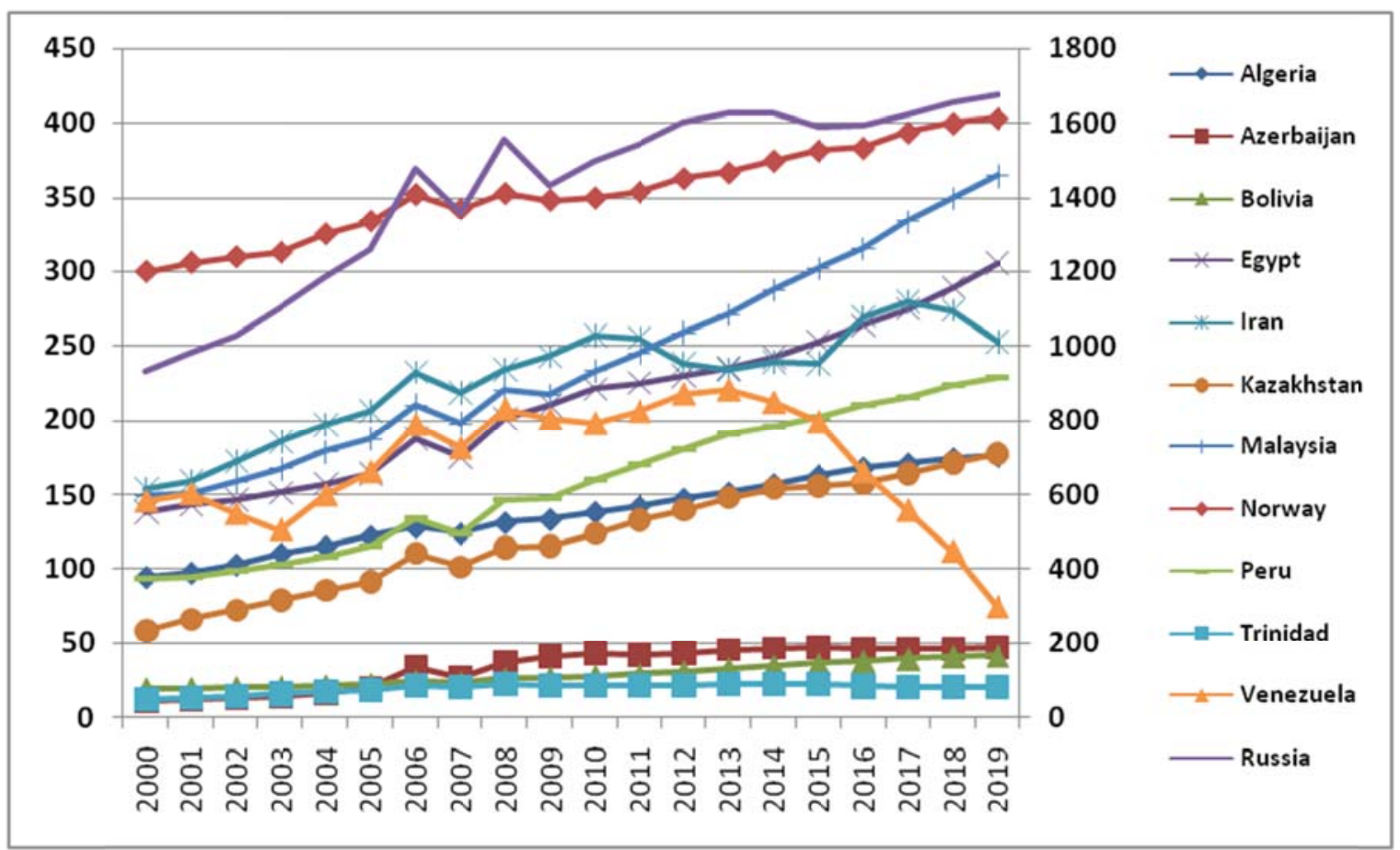

Figure 3. Real GDP (in billion USD). Right Axis: Russia

Source: Authors

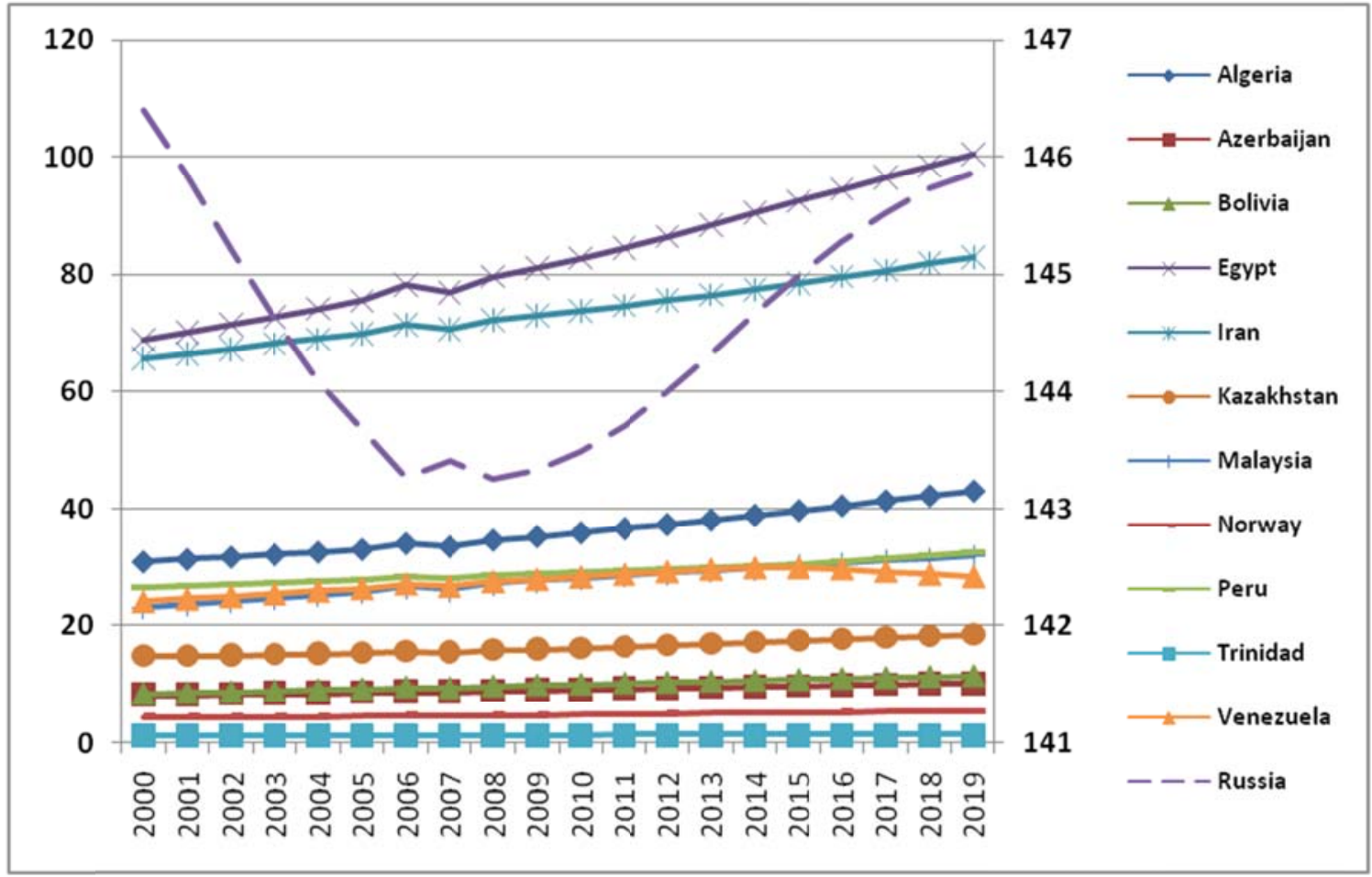

Figure 4. Population (in million). Right Axis: Russia

Source: Authors

\subsection{Unit Root Test}

As mentioned in the previous section, the bound F-test is not valid at the presence of I(2) stationary in time series. Therefore, before we proceed with ARDL bound test model, we need to ensure that none of our variables is integrated of order 2 or beyond to avoid spurious results. We applied the Augmented Dicky-Fuller (ADF) t-test. The ADF unit root test results for the variables (Table 2) indicate that none of the variables is integrated of order 
2 or behind.

Table 2. ADF Unit Root Tests on Variables

\begin{tabular}{|c|c|c|c|c|c|c|c|c|}
\hline \multirow[t]{2}{*}{ Country } & \multicolumn{2}{|c|}{ G (Gas Consumption) } & \multicolumn{2}{|c|}{ P (Gas Price) } & \multicolumn{2}{|c|}{ Y (real GDP) } & \multicolumn{2}{|c|}{ pop (population) } \\
\hline & ADF Stat & $\mathrm{I}(\mathrm{d})$ & ADF Stat & $\mathrm{I}(\mathrm{d})$ & ADF Stat & $\mathrm{I}(\mathrm{d})$ & ADF Stat & $\mathrm{I}(\mathrm{d})$ \\
\hline Algeria & $-4.61 * * *$ & $\mathrm{I}(1)$ & $-3.15 * * *$ & $\mathrm{I}(1)$ & $-5.29 * * *$ & $\mathrm{I}(1)$ & $-5.52 * * *$ & $\mathrm{I}(1)$ \\
\hline Azerbaijan & $-3.67 * *$ & $\mathrm{I}(1)$ & $-3.12^{* *}$ & $\mathrm{I}(1)$ & $-5.84 * * *$ & $\mathrm{I}(1)$ & $-7.64 * * *$ & $\mathrm{I}(1)$ \\
\hline Bolivia & $-3.10^{* *}$ & $\mathrm{I}(1)$ & $-4.09 * * *$ & $\mathrm{I}(1)$ & $-5.33 * * *$ & $\mathrm{I}(1)$ & $-5.89 * * *$ & $\mathrm{I}(1)$ \\
\hline Egypt & $-4.10 * *$ & $\mathrm{I}(1)$ & $-5.04 * * *$ & $\mathrm{I}(1)$ & $-6.5^{* * *}$ & $\mathrm{I}(1)$ & $-6.53 * * *$ & $\mathrm{I}(1)$ \\
\hline Iran & $-7.17 * * *$ & $\mathrm{I}(1)$ & $-4.37 * *$ & $\mathrm{I}(1)$ & $-9.05 * * *$ & $\mathrm{I}(1)$ & $-7.45 * * *$ & $\mathrm{I}(1)$ \\
\hline Kazakhstan & $-4.05^{* *}$ & $\mathrm{I}(0)$ & $-3.96 * *$ & $\mathrm{I}(1)$ & $-3.73 * *$ & $\mathrm{I}(0)$ & $-6.45 * * *$ & $\mathrm{I}(1)$ \\
\hline Malaysia & $-5.26^{* * *}$ & $\mathrm{I}(1)$ & $-5.20 * * *$ & $\mathrm{I}(1)$ & $-7.39 * * *$ & $\mathrm{I}(1)$ & $-5.17 * * *$ & $\mathrm{I}(1)$ \\
\hline Norway & $-5.47 * * *$ & $\mathrm{I}(1)$ & $-4.59 * * *$ & $\mathrm{I}(1)$ & $-6.03 * * *$ & $\mathrm{I}(1)$ & $-5.66 * * *$ & $\mathrm{I}(1)$ \\
\hline Peru & $-7.17 * * *$ & $\mathrm{I}(1)$ & $-6.92 * * *$ & $\mathrm{I}(1)$ & $-9.05 * * *$ & $\mathrm{I}(1)$ & $-4.02 * * *$ & $\mathrm{I}(1)$ \\
\hline Russia & $-5.98 * * *$ & $\mathrm{I}(1)$ & $-5.95 * * *$ & $\mathrm{I}(1)$ & $-7.29 * * *$ & $\mathrm{I}(1)$ & $-6.98 * * *$ & $\mathrm{I}(0)$ \\
\hline Trinidad & $-6.10 * * *$ & $\mathrm{I}(1)$ & $-3.84 * * *$ & $\mathrm{I}(1)$ & $-5.73 * * *$ & $\mathrm{I}(1)$ & $-6.86^{* * *}$ & $\mathrm{I}(1)$ \\
\hline Venezuela & $-4.82 * * *$ & $\mathrm{I}(1)$ & $-5.07 * * *$ & $\mathrm{I}(0)$ & $-4.72 * * *$ & $\mathrm{I}(1)$ & $-6.78 * * *$ & $\mathrm{I}(1)$ \\
\hline
\end{tabular}

Note. ***, ** and * denotes significance at the 1\%, 5\% and 10\% level, respectively. Results obtained from EViews 12. I(d) refers to the integration of order $d$.

4.3 Bounds Tests for Cointegration

Once we ensured that our variables are not integrated of order 2 and behind, we test for the presence of long-run relationship by estimating equation (5) for each country using EViews 12 and OLS method. According to Pesaran and Pesaran, (1997, p.305), "this OLS regression in first differences are of no direct interest" to the bounds test. Then we conduct F-test on the joint null hypothesis, that the coefficients of lagged level variables are zero, or in other words, no long-run relationship exists. Table 3 illustrates the result of F-tests for all countries. According to the results, the null hypothesis of no long-run relationship can be rejected for all countries, at least at 5\% level, except for Azerbaijan and Kazakhstan, where F-statistic indicates that no long-run relationship exists. According to Abadir and Magnus (2005), when F-statistic rejects the null hypothesis and there is long-run cointegration, three possibilities can arise: (a) the equilibrating relationship between dependent variables and repressors is entirely nonsensical; (b) the equilibrating relationship is defined, but degenerate; (c) the equilibrating relationship is well defined. Therefore, an additional T-bounds test is required to exclude the possibility (a) above. 
Table 3. Results for ARDL Bounds F-tests

\begin{tabular}{|c|c|c|c|c|}
\hline Country & Dependent Variables & F-Statistic & T-Statistic & Outcome \\
\hline Algeria & $\mathrm{F}_{\mathrm{g}}(\lg \mid \mathrm{ly}, \mathrm{lp})=$ & $5.18^{* * *}$ & $-3.93^{* *}$ & Usual cointegration \\
\hline Azerbaijan & $\mathrm{F}_{\mathrm{g}}(\lg \mid \operatorname{ly}, \mathrm{lp})=$ & $4.81 *$ & -2.64 & No cointegration \\
\hline Bolivia & $\mathrm{F}_{\mathrm{g}}(\lg \mid \operatorname{ly}, \operatorname{lp})=$ & $30.4 * * *$ & -0.33 & Nonsensical cointegration \\
\hline Egypt & $\mathrm{F}_{\mathrm{g}}(\lg \mid \operatorname{ly}, \operatorname{lp})=$ & $12.3 * * *$ & $-5.5^{* * *}$ & Usual cointegration \\
\hline Iran & $F_{g}(\lg \mid \operatorname{ly}, \operatorname{lp})=$ & $8.3^{* * *}$ & $-4.75^{* * *}$ & Usual cointegration \\
\hline Kazakhstan & $\mathrm{F}_{\mathrm{g}}(\lg \mid \operatorname{ly}, \operatorname{lp})=$ & 2.6 & 0.25 & No cointegration \\
\hline Malaysia & $F_{g}(\lg \mid \operatorname{ly}, \operatorname{lp})=$ & $4.45^{* *}$ & $-3.55^{* *}$ & Usual cointegration \\
\hline Norway & $\mathrm{F}_{\mathrm{g}}(\lg \mid \operatorname{ly}, \operatorname{lp})=$ & $4.19 * *$ & R.constant & Usual cointegration \\
\hline Peru & $\mathrm{F}_{\mathrm{g}}(\lg \mid \operatorname{ly}, \operatorname{lp})=$ & $4.33^{* *}$ & $2.78^{*}$ & Usual cointegration \\
\hline Russia & $\mathrm{F}_{\mathrm{g}}(\lg \mid \operatorname{ly}, \operatorname{lp})=$ & $11.7 * * *$ & $-5.03 * * *$ & Usual cointegration \\
\hline Trinidad & $\mathrm{F}_{\mathrm{g}}(\lg \mid \operatorname{ly}, \operatorname{lp})=$ & $15.6^{* * *}$ & $-4.89 * * *$ & Usual cointegration \\
\hline Venezuela & $\mathrm{F}_{\mathrm{g}}(\lg \mid \mathrm{ly}, \operatorname{lp})=$ & $7.88 * * *$ & $-3.89^{*}$ & Usual cointegration \\
\hline
\end{tabular}

Note. $* * *, * *$ and $*$ denotes significance at the $1 \%, 5 \%$ and $10 \%$ level, respectively. Results obtained from EViews 12.

\subsection{Long-Run Elasticities and Short-Run Dynamics Coefficients}

Bonds test results from the previous section suggest that we can proceed to estimate the long-run elasticities and short-run dynamics for ten of twelve initially considered countries including Algeria, Bolivia, Egypt, Iran, Malaysia, Norway, Peru, Russia, Trinidad and Tobago and Venezuela. Therefore, Azerbaijan and Kazakhstan were ruled out as the F-bounds test fails to reject the null hypothesis of "no long-run relationship". However, the additional T-bounds test indicates that the long run relationship for the case of Bolivia is nonsensical, and therefore, we cannot proceed further with the ARDL model and estimate the speed of adjustment. However, the T-bounds test for the two countries of Peru and Venezuela is only significant at $10 \%$ level, these two countries are still reported. Consequently, we continue with the estimation of equation (6) for nine individual countries using the Akaike Information Criterion (AIC) and the Schwarz Bayesian Criterion (SIC) to select optimal order in ARDL model specification. As explained in section 3, we ensure that the error terms of the estimated ARDL model are serially independent and homoskedastic. The results obtained and estimated parameters can be used to construct long-run elasticities as described in the equations (7) to (9).

As the next step, we are also interested in obtaining short-term dynamics coefficients associated with the long-run relationship. For this purpose, we estimate an error correction model as defined in equation (10). The obtained results for long-run elasticities and short-term dynamics coefficients are given in Table 4 and Table 5 respectively. 
Table 4. Estimated Long-Run Coefficients for preferred ARDL Model

\begin{tabular}{|c|c|c|c|c|c|c|}
\hline \multirow[t]{2}{*}{ Country } & \multirow{2}{*}{$\begin{array}{c}\text { ARDL Selected } \\
\text { Model }\end{array}$} & \multicolumn{5}{|c|}{ Long-run Coefficients } \\
\hline & & $1 \mathrm{Y}$ & $1 \mathrm{P}$ & Constant & Trend & Dummy \\
\hline Algeria & $\operatorname{ARDL}(1,0,0)$ & $\begin{array}{c}2.60 * * * \\
{[0.007]}\end{array}$ & $\begin{array}{c}-0.298 \\
{[0.164]}\end{array}$ & $\begin{array}{l}5.23 * * * \\
{[0.005]}\end{array}$ & - & - \\
\hline Egypt & $\operatorname{ARDL}(2,3,1)$ & $\begin{array}{c}-1.29 * * \\
{[0.004]}\end{array}$ & $\begin{array}{c}0.058^{*} \\
{[0.084]}\end{array}$ & $\begin{array}{l}19.6 * * * \\
{[0.001]}\end{array}$ & $\begin{array}{c}0.27 * * * \\
{[0.002]}\end{array}$ & - \\
\hline Iran & $\operatorname{ARDL}(1,0,1)$ & $\begin{array}{l}1.42^{* * *} \\
{[0.007]}\end{array}$ & $\begin{array}{c}-0.059 * * \\
{[0.018]}\end{array}$ & $\begin{array}{c}9.98 * * * \\
{[0.000]}\end{array}$ & - & $\begin{array}{l}0.104^{* *} \\
{[0.028]}\end{array}$ \\
\hline Malaysia & $\operatorname{ARDL}(2,1,2)$ & $\begin{array}{c}-5.99 * * * \\
{[0.000]}\end{array}$ & $\begin{array}{c}-1.93 * * \\
{[0.040]}\end{array}$ & $\begin{array}{c}30 * * * \\
{[0.002]}\end{array}$ & - & - \\
\hline Norway & $\operatorname{ARDL}(1,4,4)$ & $\begin{array}{c}16.3^{* *} \\
{[0.015]}\end{array}$ & $\begin{array}{c}-0.73^{*} \\
{[0.081]}\end{array}$ & $\begin{array}{l}-58.2 * * \\
{[0.025]}\end{array}$ & - & - \\
\hline Peru & $\operatorname{ARDL}(1,0,2)$ & $\begin{array}{l}10.2 * * * \\
{[0.000]}\end{array}$ & $\begin{array}{c}-2.83 * * * \\
{[0.000]}\end{array}$ & - & - & - \\
\hline Russia & $\operatorname{ARDL}(3,3,3)$ & $\begin{array}{c}0.60 * * * \\
{[0.001]}\end{array}$ & $\begin{array}{c}-0.51 * * * \\
{[0.000]}\end{array}$ & $\begin{array}{c}23.5^{* * *} \\
{[0.000]}\end{array}$ & - & - \\
\hline Trinidad & $\operatorname{ARDL}(4,3,3)$ & $\begin{array}{c}-0.95 * * \\
{[0.021]}\end{array}$ & $\begin{array}{c}0.42 * * * \\
{[0.010]}\end{array}$ & $\begin{array}{l}44.4^{* *} \\
{[0.045]}\end{array}$ & $\begin{array}{c}-0.15 * * \\
{[0.038]}\end{array}$ & - \\
\hline Venezuela & $\operatorname{ARDL}(2,3,1)$ & $\begin{array}{c}0.99 * * * \\
{[0.005]}\end{array}$ & $\begin{array}{c}0.01 \\
{[0.638]}\end{array}$ & $\begin{array}{l}12.7 * * * \\
{[0.002]}\end{array}$ & $\begin{array}{c}-0.05 * * * \\
{[0.002]}\end{array}$ & - \\
\hline & MEAN & 2.65 & -0.79 & 10.9 & 0.023 & 0.104 \\
\hline & MIN & -5.99 & -2.83 & -58.2 & -0.15 & 0.104 \\
\hline & MAX & 16.3 & 0.42 & 44.4 & 0.27 & 0.104 \\
\hline \multicolumn{7}{|c|}{$\begin{array}{l}\text { Note. Trend, Constants and dummy are entered as fixed regressors. P-values are reported in brackets. ***,**, } \\
\text { denote significance at the } 1 \%, 5 \% \text { and } 10 \% \text { level, respectively. Mean, MIN and MAX refer to significan } \\
\text { estimates only. Results obtained from EViews } 12 \text {. }\end{array}$} \\
\hline \multirow[t]{2}{*}{ Country } & \multicolumn{6}{|c|}{ Short-run Dynamics Coefficients } \\
\hline & \multicolumn{2}{|c|}{ ECT(-1) (Speed of adjustment) } & \multicolumn{2}{|c|}{$\Delta\left(\operatorname{lp}_{\mathrm{t}}\right)$} & $\Delta\left(\mathrm{ly}_{\mathrm{t}}\right)$ & $\mathrm{R}^{2}$ \\
\hline Algeria & \multicolumn{2}{|c|}{$\begin{array}{c}-0.55^{* * *} \\
{[0.000]}\end{array}$} & \multicolumn{2}{|c|}{ - } & - & 0.50 \\
\hline Egypt & & $-2.22 * * *$ & \multicolumn{2}{|c|}{$0.17^{*}$} & $\begin{array}{c}-2.13 * * * \\
{[0.005]}\end{array}$ & 0.87 \\
\hline Iran & & *** & \multicolumn{2}{|c|}{0.04} & - & 0.95 \\
\hline Malaysia & \multicolumn{2}{|c|}{$-1.05 * * *$} & \multicolumn{2}{|c|}{-0.76} & -6.31 & 0.66 \\
\hline Norway & \multicolumn{2}{|c|}{$-1.77 * * *$} & \multicolumn{2}{|c|}{0.25} & $22.3 * * *$ & 0.85 \\
\hline
\end{tabular}




\begin{tabular}{lcccc}
\hline \multirow{2}{*}{ Peru } & {$[0.005]$} & {$[0.328]$} & {$[0.011]$} & \\
& $-0.31^{* * *}$ & - & $22^{* * *}$ & 0.72 \\
Russia & {$[0.001]$} & - & {$[0.000]$} & \\
& $-1.71^{* * *}$ & -0.08 & $-0.83^{* *}$ & 0.94 \\
Trinidad & {$[0.000]$} & {$[0.240]$} & {$[0.023]$} & \\
& $-3.61^{* * *}$ & $-0.19^{*}$ & $-1.42^{* *}$ & 0.98 \\
Venezuela & {$[0.010]$} & {$[0.078]$} & {$[0.038]$} & \\
& $-1.55^{* * *}$ & -0.05 & $2.06^{* * *}$ & 0.93 \\
MEAN & {$[0.000]$} & {$[0.115]$} & {$[0.001]$} & \\
MIN & -1.51 & -0.02 & 6.99 & 0.82 \\
MAX & -3.61 & -0.19 & -2.13 & 0.50 \\
\hline
\end{tabular}

Note. P-values are reported in brackets. ***,**** denote significance at the $1 \%, 5 \%$ and $10 \%$ level, respectively. Mean, MIN and MAX refer to significant estimates only. Short term coefficients for the lag length of one are only reported. $\mathrm{R}^{2}$ denotes the coefficient of determination. Results obtained from EViews 12.

4.5 Diagnostic and Stability Tests

\subsubsection{Residual Diagnostics}

Table 6 provides residual diagnostic tests of no serial correlations, normality and homoscedasticity. These tests investigate that there is no problem with selected ARDL models. According to test results, all models pass all the tests, except Peru, whose test detects a heteroskedasticity problem and this has been taken into consideration using Autocorrelation Consistent (HAC) covariance matrix estimators.

Table 6. Diagnostic tests for preferred ARDL models

\begin{tabular}{cccc}
\hline Country & Serial Correlation & Normality & Heteroscedasticity \\
\hline Algeria & 0.30 & 2.98 & 0.89 \\
& {$[0.745]$} & {$[0.224]$} & {$[0.464]$} \\
Egypt & 3.48 & 1.03 & 1.03 \\
& {$[0.112]$} & {$[0.595]$} & {$[0.491]$} \\
Iran & 0.39 & 0.79 & 0.59 \\
& {$[0.684]$} & {$[0.672]$} & {$[0.702]$} \\
Malaysia & 0.50 & 0.59 & 1.59 \\
& {$[0.621]$} & {$[0.743]$} & {$[0.241]$} \\
Norway & 2.28 & 0.08 & 0.76 \\
& {$[0.304]$} & {$[0.959]$} & {$[0.672]$} \\
Peru & 0.60 & 0.37 & $3.35 * *$ \\
& {$[0.561]$} & {$[0.827]$} & {$[0.039]$} \\
Russia & 1.18 & 0.186 & 2.35 \\
& {$[0.379]$} & {$[0.910]$} & {$[0.177]$} \\
Trinidad & 1.21 & 1.10 & 0.85 \\
& {$[0.469]$} & {$[0.576]$} & {$[0.658]$} \\
Venezuela & 1.18 & 1.08 & 1.87 \\
& {$[0.379]$} & {$[0.582]$} & {$[0.215]$} \\
\hline
\end{tabular}

Note. P-values are reported in brackets. ${ }^{* * *}, * *, *$ denote significance at the $1 \%, 5 \%$ and $10 \%$ level, respectively. Normality test is based on a test of skewness and kurtosis of residuals. Results obtained from EViews 12. 


\subsubsection{Stability Test}

Test for parameter stability over the sample is important to ensure that model's parameters will not change in the sample period. For this purpose, we employ the recursive estimation methods of CUSUM and the CUSUMSQ to evaluate parameter stability. Figure 5 plots CUSUM and CUSUMSQ for each ARDL model. As it can be seen, all countries pass the CUSUM stability test. Considering CUSUMSQ, however, Peru and Russia show some concerns. For Peru, CUSUMSQ plots cross the upper 5\% critical bound, while for Russia, it crosses the lower 5\% critical bound. For all other models, the stability tests show overall parameter stability over the sample period (Appendix A).

\section{Discussion and Policy Recommendation}

In this paper, we attempted to investigate the responsiveness of residential sector gas demand in some gas exporting countries to changes in the real gas price and real disposable income. We employed the ARDL bound test cointegration approach developed by Pesaran and Shin (1999) and Pesaranet al. (2001) to estimate long-run and short term dynamic elasticities using annual data from 2000 to 2019.

Bound F-test cointegration approach has the advantage, that it does not require pretest for singles variables stationary. Meanwhile, using an error correction model, short-run elasticities, as well as the speed of adjustment to long-run equilibrium were provided.

Only 12 countries of 19 GECF countries consume gas in their residential sector. Asignificant long-run relationship was found between 9 countries, including Algeria, Egypt, Iran, Malaysia, Norway, Peru, Russia, Trinidad and Tobago and Venezuela.

Paper findings on the long-run coefficient for Algeria indicate that long-run income elasticity is 2.60 and very significant, while the long-run price elasticity is -0.29 and is statistically insignificant. In case of Egypt, although, both coefficients are significant at least at $10 \%$ significance level price, as well as income elasticity sign does not follow our expectation. We estimate Egypt long-run income elasticity at -1.29 and long-run price elasticity is measured at 0.06 . For Iran, both coefficients are significant at least at a 5\% significance level. The long-run income elasticity is 1.42 , which is elastic, whereas the long-run price elasticity is -0.06 , which is inelastic, and both show correct expected sign. Although, for Malaysia, the long-run income elasticity is very significant, the sign is not consistent with our expectation (-5.99). The long-run price elasticity for Malaysia is -1.93 and significant at $5 \%$ level. Both income and price elasticities for Norway are significant at least at $10 \%$ level, with coefficients of 16.3 and -0.73 , respectively. Long-run income elasticity for Peru is estimated at 10.2 and this figure for price elasticity is -2.83 . Both are very elastic and statistically very significant. For Russia, the result indicates that both long-run price and income elasticities are inelastic with -0.51 and 0.6 , respectively. For Trinidad and Tobago, long-run price elasticity is estimated at 0.42 , however, the sign is positive. Additionally, for long-run income elasticity, the sign is not in line with our expectation (-0.95). Finally, for Venezuela, long-run price elasticity does not differ from zero, and is insignificant, but long-run income elasticity is estimated at near unity (0.99), and significant at $5 \%$ level.

On average, accounting for only significant coefficients, the long-run income elasticity for underlying GECF gas exporting countries is 2.65 , while long-run price elasticity is calculated at -0.79 . This indicates that in considered gas exporting countries, residential sector gas demand is very sensitive to income policies, while the price policies impact on demand is limited. Furthermore, long-run income elasticity is greater than unity, indicating that residential sector gas demand grows at a greater rate than income, resulting in higher intensity of gas demand over time. This is consistent with the observation, that natural gas's share of the global energy mix often increases as economies grow (Burke, 2013). In addition to income growth, switching to natural gas is currently being spurred by the price-reducing effects of a supply-side boom in unconventional gas in the United States and elsewhere (Burke and Yang, 2016).

Despite sporadic outcomes for long-run elasticities, all the estimated coefficients for speed of adjustment to long-run equilibrium are very significant at a $1 \%$ significance level and have the correct expected sign, i.e. negative. The equilibrium correction coefficient range between -0.31 and -3.61 with an average of -1.51 . Narayan and Smyth (2006) assume that this value "implies that instead of monotonically converging to the equilibrium path directly, the error correction process fluctuates around the long-run value in a dampening manner." And therefore economy returns rapidly to equilibrium once the process is complete.

The short-run dynamics elasticities of income and price are also measured by the estimation of the error correction model. However, in most cases, short-run elasticities neither are in line with the expected sign nor is significant at $10 \%$ level. 
On average, taking into account only significant coefficients, short-run income and price elasticities of underlying gas exporting countries are -0.02 and 6.99 respectively, indicating that price policies are unable to make significant changes in demand. As a result, we may argue that $\mathrm{CO} 2$ emissions policies, for instance, are not greatly affected by energy price changes. Meanwhile, as expected short-run price elasticity is lower than the long-run elasticity specifies that countries are more responsive in longterm than shortterm.

Finally, the analysis of individual country price and income elasticities indicates that the results of the estimation for short-run elasticities are not satisfying. However, while this can be a topic for further research, it can be also argued that massive subsidies paid by most gas exporting countries have distorted market functions and resulted in much less meaningful elasticities in short term. Meanwhile, it is also interesting to examine cross-price elasticities in our study by including relevant alternative fuel prices.

The policy recommendation is that the governments of gas exporting countries should try to reduce or remove subsidies on gas prices, orthey should give more attention to non-price policies rather than price-based policies to affect consumer behaviour, especially over the short term, as huge subsidies havedistorted market functions and made gas demand consumers very inelastic to price mechanism.

\section{References}

Afimia, Emmanuel. (2019). Estimating Natural Gas Demand Elasticities in Nigeria. Journal of Energy Research and Reviews, 1-12. https://doi.org/10.9734/jenrr/2019/v2i430084

Alberini, A., O. Khymych, \& M. Scasny. (2020). Responsiveness to Energy Price Changes when Salience is High: Residential Natural Gas Demand in Ukraine. Energy Policy, 144, 111534. https://doi.org/10.1016/j.enpol.2020.111534

Alberini, Anna, Will Gans, \& Daniel Velez-Lopez. (2011). Residential Consumption of Gas and Electricity in the U.S.: The Role of Prices and Income. Energy Economics, 33(5), 870-881. https://doi.org/10.1016/j.eneco.2011.01.015

Andersen, T. B., Nilsen, O. B., \& Tveteras, R. (2011). How is demand for natural gasdetermined across European industrial sectors? Energy Policy, 39, 5499-508. https://doi.org/10.1016/j.enpol .2011.05.012

Arora, V. (2014). Estimates of the price elasticities of natural gas supply and demand in the United States. MPRA Paper No. 54232. https://mpra.ub.uni-muenchen.de/id/eprint/54232

Asche, F., Nilsen, O. B., \& Tveteras, R. (2008). Natural gas demand in the European householdsector. The Energy Journal, 29(3), 27-46. https://doi.org/10.5547/ISSN0195-6574-EJ-Vol29-No3-2

Berkhout, P. H. G., Ferrer-i-Carbonell, A., \& Muskens, J. C. (2004). The ex-post impact of anenergy tax on household energy demand. Energy Economics, 26(3), 297-317. https://doi.org/10.1016/j.eneco.2004.04.002

Bilgili, F. (2014). Long-run elasticities of demand for natural gas: OECD paneldata evidence. Energy Source Part B, 9, 334-41. https://doi.org/10.1080/15567 249.2010.49779 3

Boug, Pal. (2000). Modelling energy demand in Germany: A cointegration approach. Statistics Norway, Research Department.

Burke, P. J., \& H. Yang. (2016). The Price and Income Elasticities of Natural Gas Demand. International Evidence. Energy Economics, 59, 466-74. https://doi.org/10.1016/j.eneco.2016.08.025

Dilaver, Ö., Dilaver, Z., \& Hunt, L. C. (2014). What drives natural gas consumptionin Europe? Analysis and projections. J Nat Gas Sci Eng, 19, 125-36. https://doi.org/10.1016/j.jngse .2014.04.002

Dong, K., Dong, X., \& Sun, R. (2019). How did the price and income elasticities of natural gas demand in China evolve from 1999 to 2015? The role of natural gas price reform. Pet. Sci. 16, 685-700. https://doi.org/10.1007/s12182-019-0320-z

Frimpong, J. M., \& Oteng-Abayie, E. F. (2006). Bounds Testing Approach: an examination of foreign investment, trade, and growth relationships. MPRA Paper No.352.

Gao, J., Peng, B., \& Smyth, R. (2020). On income and price elasticities for energy demand: A panel data study, Energy Economics, 96, 105-168. https://doi.org/10.1016/j.eneco.2021.105168

Gujarati, D. (2009). Basic Econometrics-Fifth Edition. The McGraw-Hill Companies.

Joutz, F. L., Shin, D., McDowell, B., \& Trost, R. P. (2008). Estimating regional short-run andlong-run price elasticities of residential natural gas demand in the U.S., $28^{\text {th }}$ US AEE/IAEE Annual North American Conference, New Orleans, LA, December 3-5. https://doi.org/10.2139/ssrn.1444927 
Liddle, B., Smyth, R., \& Zhang, X. (2020), Time-varying income and price elasticities forenergy demand: Evidence from a middle-income panel. Energy Economics, 86, 1-10. https://doi.org/10.1016/j.eneco.2020.105009

Lin, W. T., Chen, Y. H., \& Chatov, R. (1987). The demand for natural gas, electricity and heating oil in the United States. Resources and Energy, 9(3), 233-258. https://doi.org/10.1016/0165-0572(87)90009-0

Madlener, R., \& R. Bernstein. (2011). Residential Natural Gas Demand Elasticities in OECDCountries: An ARDL Bounds Testing Approach. Aachen, Germany: Institute for Future EnergyConsumer Needs and Behaviour. Working Paper No. 15. https://doi.org/10.2139/ssrn.2078036

Markos, F., \& Chahir, Z. (2021). Price and Income Elasticities of Natural Gas Demand in Egypt: A Bound Test Approach. Review of Middle East Economics and Finance. https://doi.org/10.1515/rmeef-2020-0028

Maximilian, A., \& Rubin, E. (2018), Natural Gas Price Elasticities and Optimal Cost Recovery Under Consumer Heterogeneity: Evidence from 300 million natural gas bills, NBER working paper 24295, Cambridge, MA, February.

Narayan, P. K., \& Smyth, R. (2006), What determines migration flows from low-income to highincomecountries? An empirical investigation of Fiji-US migration 1972-2001. Contemporary Economic Policy, 24(2), 332-342. https://doi.org/10.1093/cep/byj019

Olsen, O. (1988). Modelling demand for natural gas. A review of various approaches. Statistic Sentralbyra.

Otsu, T. (2006). MATRIX ALGEBRA, by Karim M. Abadir and Jan R. Magnus, Cambridge University Press, 2005. Econometric Theory, 22(5), 968-972. https://doi.org/10.1017/S0266466606000454

Payne, J. E. (2011). US Disaggregate Fossil Fuel Consumption and Real GDP: An Empirical Note. Energy Sources Part B: Economics. Planning and Policy, 6(1), 63-8. https://doi.org/10.1080/15567240902839278

Pesaran, M. H., \& Pesaran, B. (1997). Working with Microfit 4.0: Interactive Econometric Analysis, Oxford University Press, Oxford.

Pesaran, M., \& Shin, Y. (1999). An Autoregressive Distributed-Lag Modelling Approach to Cointegration Analysis. In S. Strøm (Ed.), Econometrics and Economic Theory in the 20th Century: The Ragnar Frisch Centennial Symposium (Econometric Society Monographs, pp. 371-413). Cambridge: Cambridge University Press. https://doi.org/10.1017/CCOL521633230.011

Pesaran, M. H., Shin, Y., \& Smith, R. J. (2001). Bounds testing approaches to the analysis of level relationships. Journal of Applied Econometrics, 16, 289-326. https://doi.org/10.1002/jae.616

Pesaran, M. H., Smith, R. P., \& Akiyama, T. (1998). Energy Demand in Asian Developing Economies.Oxford University Press, Oxford.

Sun, C., \& Ouyang, X. (2016). Price and expenditure elasticities of residentialenergy demand during urbanization: an empirical analysis based on the household-level survey data in China. Energy Policy, 88, 56-63. https://doi.org/10.1016/j.enpol .2015.10.012 


\section{Appendix A}

Stability test for ARDL Models
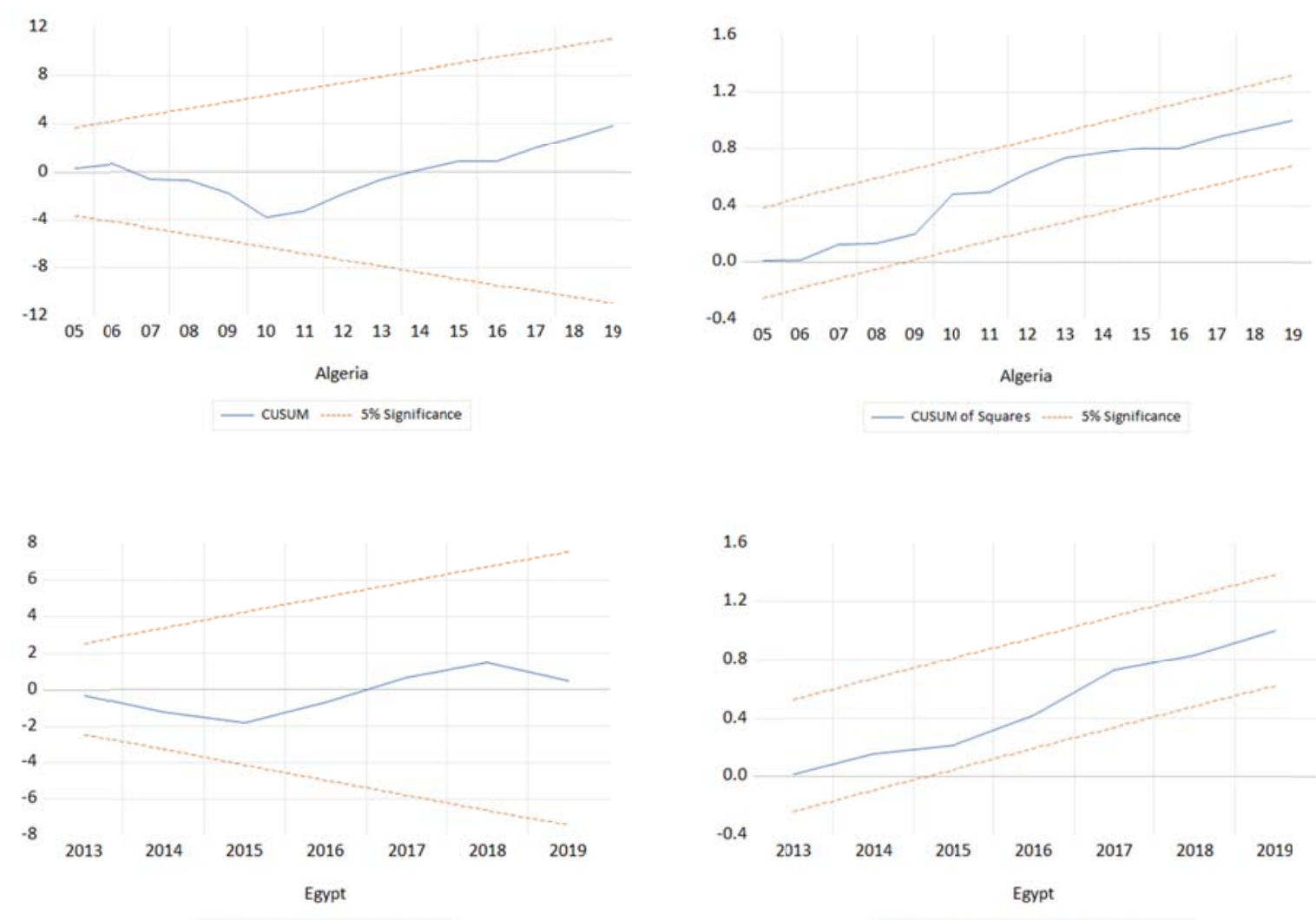

- CusuM - $5 \%$ significance

_ cusum of Squares _- $5 \%$ Significance
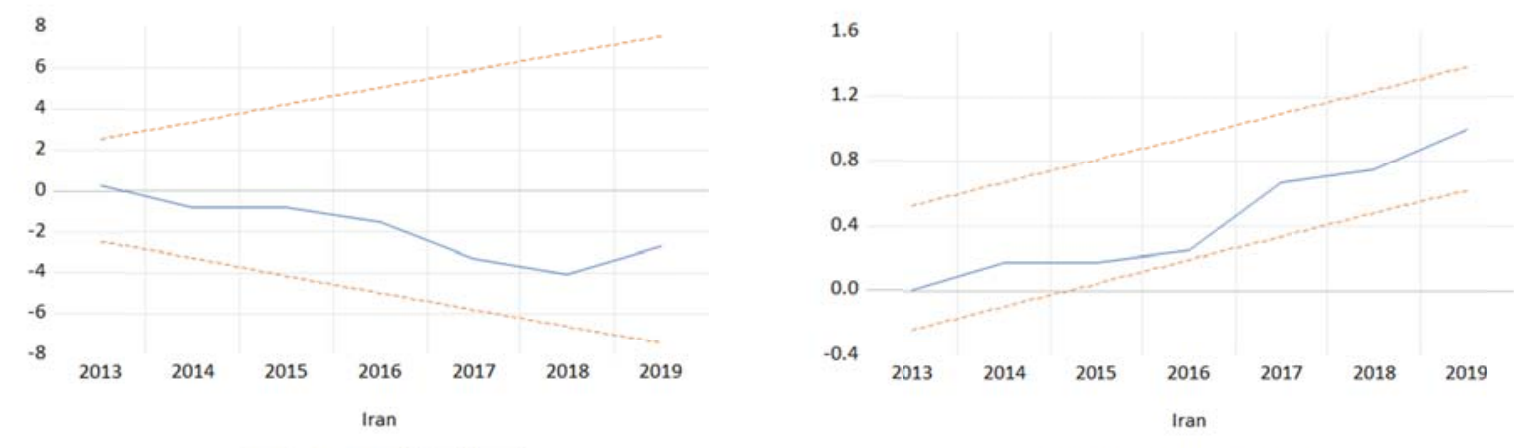

— Cusum -...- $5 \%$ Significance

— cusum of Squares —_ $5 \%$ Significance 

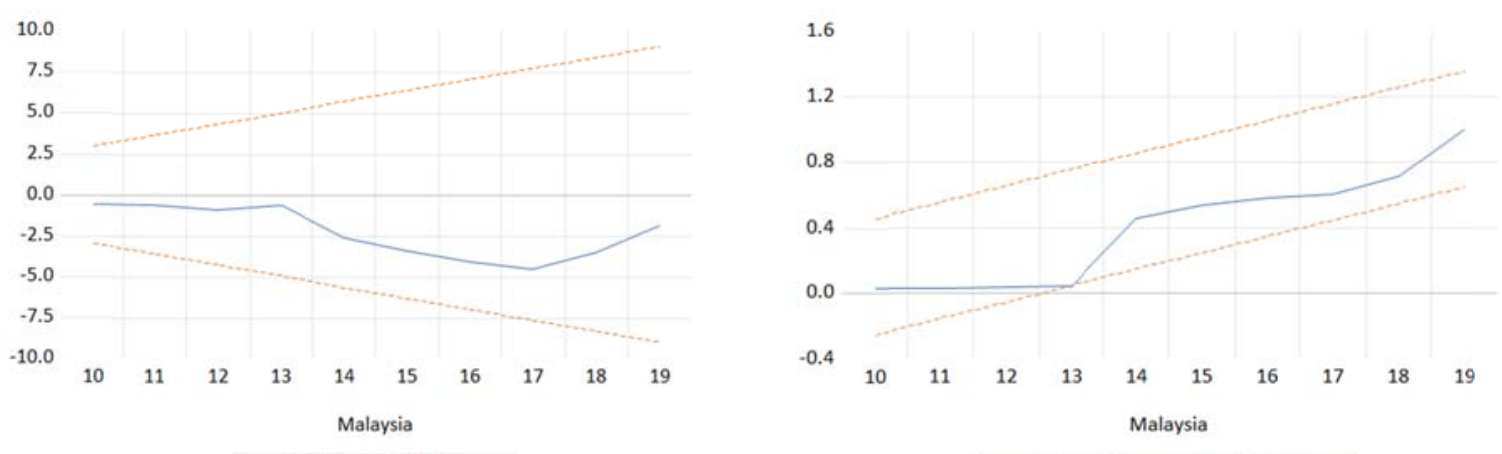

— Cusum — $5 \%$ Significance

_ CusuM of Squares _-... $5 \%$ Significance
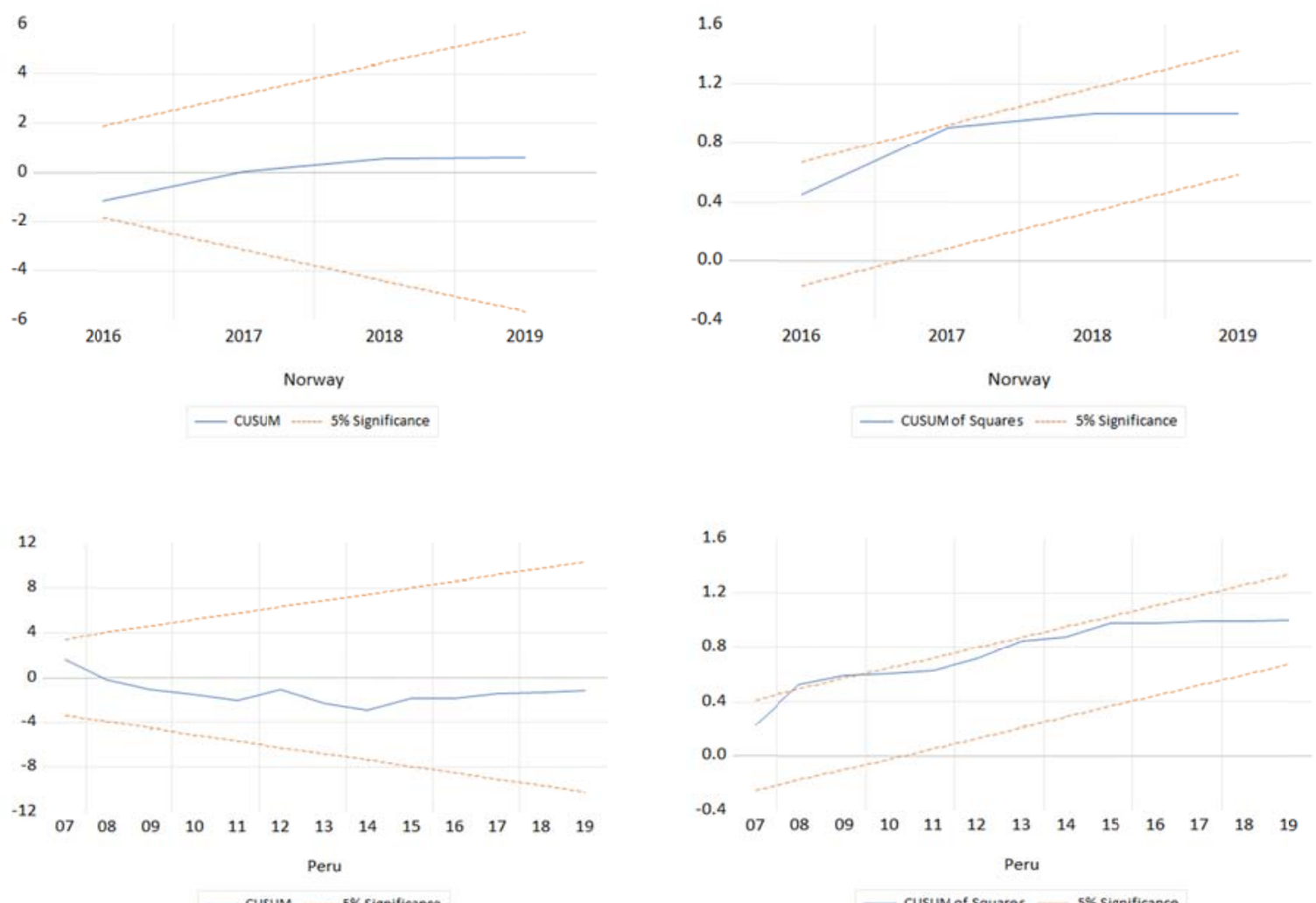

— cusum -... $5 \%$ significance

_ Cusum of Squares _-_ $5 \%$ Significance
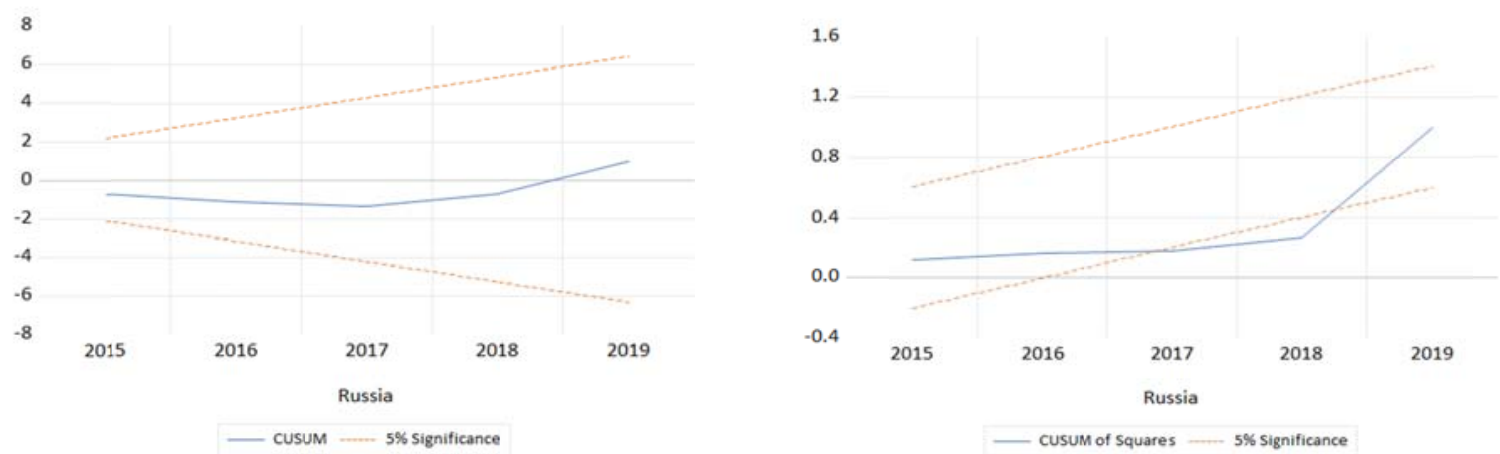

_ cusum of Squares _- $5 \%$ Significance 

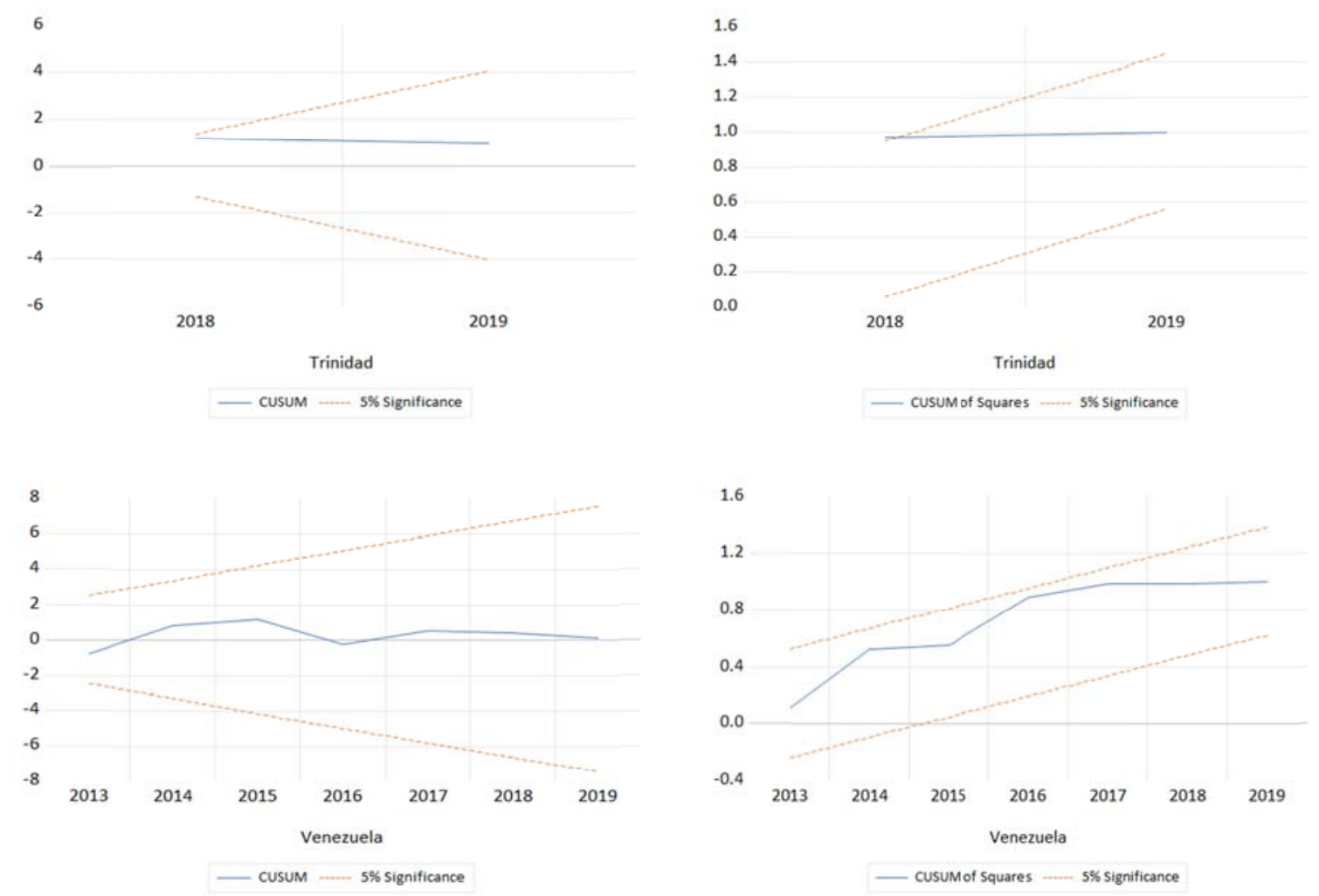

\section{Copyrights}

Copyright for this article is retained by the author(s), with first publication rights granted to the journal.

This is an open-access article distributed under the terms and conditions of the Creative Commons Attribution license (http://creativecommons.org/licenses/by/3.0/). 